\title{
Organic Anion Transporter Protein
}

National Cancer Institute

\section{Source}

National Cancer Institute. Organic Anion Transporter Protein. NCI Thesaurus. Code C107150.

A family of transmembrane proteins that play a role in the transport of organic anions including bile acids and bilirubin. 